107 Royal Netherlands Institute for Sea Research

This is a postprint of:

Weijers, J.W.H., Schefuß, E., Kim, J.-H., Sinninghe Damsté, J.S., \& Schouten, S. (2014). Constraints on the sources of branched tetraether membrane lipids in distal marine sediments. Organic Geochemstry, 72, 14-22

Published version: $\underline{\text { dx.doi.org/10.1016/j.orggeochem.2014.04.011 }}$

Link NIOZ Repository: $\underline{w w w . v l i z . b e / n l / i m i s ? m o d u l e=r e f \& r e f i d=240760}$

[Article begins on next page]

The NIOZ Repository gives free access to the digital collection of the work of the Royal Netherlands Institute for Sea Research. This archive is managed according to the principles of the Open Access Movement, and the Open Archive Initiative. Each publication should be cited to its original source - please use the reference as presented.

When using parts of, or whole publications in your own work, permission from the author(s) or copyright holder(s) is always needed. 


\title{
Constraints on the sources of branched tetraether membrane lipids in distal marine sediments
}

\author{
Johan W.H. Weijers ${ }^{\mathrm{a}, 1,2}$, Enno Schefuß ${ }^{\mathrm{b}}$, Jung-Hyun Kim ${ }^{\mathrm{c}}$, Jaap S. Sinninghe Damsté ${ }^{\mathrm{a}, \mathrm{c}}$ and \\ Stefan Schouten ${ }^{\text {a,c }}$ \\ ${ }^{a}$ Utrecht University, Department of Earth Sciences - Geochemistry, Budapestlaan 4, 3584 CD Utrecht, \\ The Netherlands \\ ${ }^{b}$ MARUM - Center for Marine Environmental Sciences, University of Bremen, Leobener Strasse, D- \\ 28359 Bremen, Germany (schefuss@uni-bremen.de) \\ ${ }^{c}$ NIOZ Royal Netherlands Institute for Sea Research, Department of Marine Organic Biogeochemistry, \\ PO Box 59, 1790 AB Den Burg, The Netherlands (Jung-Hyun.Kim@nioz.nl; Jaap.Damste@nioz.nl; \\ Stefan.Schouten@nioz.nl)
}

${ }^{1}$ Present address: Shell Global Solutions International B.V., Kessler Park 1, 2288 GS Rijswijk, The Netherlands (johan.weijers@shell.com)

${ }^{2}$ Corresponding author (johan.weijers@ shell.com; phone: +31-70-4476229) 


\section{Abstract}

3 Branched glycerol dialkyl glycerol tetraethers (brGDGTs) are membrane lipids produced by soil

4 bacteria and occur in near coastal marine sediments as a result of soil organic matter input. Their

5 abundance relative to marine-derived crenarchaeol, quantified in the BIT index, generally

6 decreases off-shore. However, in distal marine sediments, low relative amounts of brGDGTs can

7 often still be observed. Sedimentary in-situ production as well as dust input has been suggested

8 as potential, though as yet not well constrained, sources. In this study brGDGT distributions in

9 dust are examined and compared with those in distal marine sediments. Dust was sampled along

10 the equatorial West African coast and brGDGTs were detected in most of the samples, albeit in

11 low abundance. Their degree of methylation and cyclisation, expressed in the MBT'

12 (methylation index of branched tetraethers) and DC (degree of cyclisation) indices, respectively,

13 were comparable to those found for African soils, their presumed source. Comparison of DC

14 indices of brGDGTS in global soils, Congo deep-sea river fan sediments and dust with those of

15 distal marine sediments, however, clearly shows that distal marine sediments yield significantly

16 higher DC indices. This distinctive distribution is suggestive of sedimentary in-situ production as

17 source of brGDGTs in marine sediments, rather than dust input. The presence of in-situ produced

18 brGDGTs in marine sediments means that caution should be exercised when applying the MBT'-

19 CBT palaeothermometer in sediments with low BIT indices, i.e. $<0.1$ based on our dataset.

22 Keywords: Branched Tetraether; Dust; Marine Surface Sediment 


\section{Introduction}

25 Marine sediments provide a unique archive to study Earth's past environment and climate.

26 Depending on the proximity of the study location to land, a varying proportion of the organic

27 matter $(\mathrm{OM})$ input in marine sediments may be land derived. This terrigenous OM can be

28 delivered to marine sediments by several modes of transport, i.e. eolian dust input, suspended in

29 river water, or by means of gravity transport over the sea bed like through deep see canyons or in

30 turbidites. Several proxies have been developed that try to distinguish between marine and

31 terrigenous derived OM. These can be either based on bulk properties like the C:N ratio and the

32 stable carbon isotopic $\left(\delta^{13} \mathrm{C}\right)$ composition of OM (Hedges et al., 1997 and references therein), or

33 based on the molecular composition, e.g. the (relative) abundance of lignin phenols (e.g. Goñi et

34 al., 1997) or other land specific biomarkers like long chain plant-wax derived $n$-alkanes

35 (Eglinton et al., 1962) or taraxerol (Killops and Frewin, 1994; Versteegh et al., 2004).

36

37 More recently, branched Glycerol Dialkyl Glycerol Tetraether (brGDGT) membrane lipids (Fig.

38 1) have been used as terrigenous biomarkers in marine sediments as they derive from soil

39 bacteria, likely belonging to the phylum of Acidobacteria (Sinninghe Damsté et al., 2000, 2011;

40 Weijers et al., 2006b, 2009a), and since their abundance in marine sediments quickly decreases

41 with increasing distance from the coast (Hopmans et al., 2004; Kim et al., 2006; Herfort et al.,

42 2006). Hopmans et al. (2004) proposed the Branched vs. Isoprenoid Tetraether (BIT) index to

43 quantify the relative abundance of these brGDGTs in marine sediments by normalising them to

44 crenarchaeol, an isoprenoid GDGT membrane lipid derived from ubiquitous pelagic

45 Thaumarchaeota (Sinninghe Damsté et al., 2002). It was suggested that this BIT index can be 
used as proxy to trace terrigenous OM input into marine sediments (Hopmans et al., 2004).

47 However, subsequent studies demonstrated that the BIT index actually traces soil rather than terrigenous OM input relative to marine OM input in near coastal marine sediments as brGDGTs are present in soils and not in vegetation (Huguet et al., 2007; Walsh et al., 2008; Kim et al., 2009; Weijers et al., 2009b; Smith et al., 2012).

Besides information on soil OM input, brGDGT distributions also provide information on

54 position (and recently it has been shown that methylation at the C6 and C6' position also occurs;

55 De Jonge et al., 2013), and contain one or two cyclopentane moieties (Weijers et al., 2006a). In a 56 set of soils obtained from across the globe, it was found that the degree of cyclisation, expressed 57 in the Cyclisation ratio of Branched Tetraethers (CBT), shows a strong relation with soil $\mathrm{pH}$, and 58 the degree of branching, expressed in the Methylation index of Branched Tetraethers (MBT), 59 shows a strong relation with both soil $\mathrm{pH}$ and annual Mean Air Temperature (MAT, Weijers et al., 2007b). Upon transport of brGDGTs to the marine environment and deposition in the marine

61 sedimentary archive, their distribution could hence be used to reconstruct past soil $\mathrm{pH}$ and past

62 annual MAT using these parameters in the so-called MBT-CBT proxy (e.g. Weijers et al., 63 2007a). Recently the MBT index has been slightly modified (referred to as MBT') by excluding 64 two brGDGTs from analysis that usually occur in low abundance (i.e. <1 \% of total brGDGTs) in 65 soils (Peterse et al., 2012). That same study also provided a new calibration for the MBT'-CBT 66 annual MAT proxy using this MBT' and based on a larger number of soils. In addition to the 67 CBT ratio, Sinninghe Damsté et al. (2009) introduced the degree of cyclisation (DC) index in 
order to define the degree of cyclisation of brGDGTs in a similar way as the degree of methylation in the MBT index, enabling a more direct comparison between the two.

Application of the BIT index and the MBT'-CBT proxy in marine sediments works under the assumption that crenarchaeol is produced in the marine realm and brGDGTs are derived from land. It has, however, been shown that Thaumarchaeota also thrive in soils, peat, lakes and river water and hence that crenarchaeol is produced in these environments as well (e.g. Weijers et al., 2004, 2006b; Powers et al., 2004; Leininger et al., 2006; Bannert et al., 2011; Zell et al., 2013). The amount of crenarchaeol in soil and peat is, however, generally low relative to brGDGTs causing soils and peat to be, on average, still characterised by a high BIT index value though rarely reaching a value of 1 ( 0.90 on average; Schouten et al., 2013a and references cited therein). A similar situation is observed in marine settings: although the BIT index in distal marine settings is often low, it seldom reaches a value of 0 (average 0.04 ; Schouten et al., 2013a) as in most distal marine sediments small amounts of brGDGTs remain detectable. The sources of these brGDGTs are uncertain. Long distance dust transport over the oceans might be a plausible mechanism for delivery of brGDGTs to remote ocean settings and brGDGTs have indeed been reported in atmospheric dust sampled off northwest Africa (Fietz et al., 2013). Alternatively, brGDGTs could be produced in-situ in marine sediments as suggested for near shore marine sediments in a Svalbard fjord (Peterse et al., 2009) and in East China Sea sediments (Zhu et al., 2011) based on differences in brGDGT distributions in marine sediments vs. soils on adjacent land. However, it remains unclear to what extent these findings represent local, near coastal insitu production, or that marine in-situ production of brGDGTs is a more general phenomenon. 
91 To investigate whether dust or in-situ production is responsible for the presence of brGDGTs in

92 distal marine sediments, we analysed the distribution of brGDGTs in atmospheric dust and

93 marine surface waters from the coast of western Africa and in globally distributed open ocean

94 sediments. These data are compared with previously published brGDGT distributions from the

95 western African Congo deep sea river fan sediments and with global soils in order to constrain

96 the potential source of brGDGTs in distal marine sediments and to identify potential implications

97 for the use of GDGT-based proxies.

98

99

100

2. Material and methods

101

\subsection{Samples}

Atmospheric dust was sampled along the west coast of equatorial Africa onboard the R/V Meteor

102 cruise M41/1 in 1998. Details on sampling and extraction procedures are provided by Schefuß et

103 al. (2003). For the present study, polar fractions of lipid extracts from 13 dust filters (Table 1;

104 Fig. 2) were dried, redissolved in $n$-hexane:iso-propanol 99:1 (v/v), and filtered through a 0.45

$105 \mu \mathrm{m}$ mesh PTFE filter prior to analysis of their GDGT content.

106 Suspended particulate matter (SPM) in marine surface waters was sampled by filtration of ca.

107100 to $400 \mathrm{~L}$ water, provided by the ship's seawater inlet (ca. $5 \mathrm{~m}$ water depth), through a $0.7 \mu \mathrm{m}$

108 GFF filter onboard R/V Meteor during cruise M56 in December 2002 along the west coast of

109 equatorial Africa (Spiess and Cruise Participants, 2008). The eight sampling locations comprise a

110 transect along the equatorial African coast and include the lower salinity (down to $28.0 \%$ )

111 Congo River outflow plume (Table 2; Fig. 2). Filters were freeze dried, cut into small pieces and

112 extracted using a dichloromethane (DCM):methanol (MeOH) 9:1 (v/v) mixture using accelerated

113 solvent extraction (Dionex ASE $200,100^{\circ} \mathrm{C}, 1000 \mathrm{psi}, 3$ cycles of $5 \mathrm{~min}$ ). The obtained total 
114 lipid extract was saponified with $6 \% \mathrm{KOH}\left(2 \mathrm{~h}\right.$ at $\left.85^{\circ} \mathrm{C}\right)$ and the extracted neutral fraction was 115 dried and separated over pre-combusted silica gel columns into an apolar, a ketone, and a polar

116 fraction using $n$-hexane, DCM, and DCM:MeOH 1:1 (v/v) solvent mixtures, respectively.

117 Further preparation of the polar fractions was similar to that of the dust samples.

118 A total of 34 distal marine surface sediments (Table 3) were analysed for their brGDGT content.

119 These sediments were selected from the core-top calibration data set used for the TEX 86 sea 120 surface temperature proxy, based on their low BIT index, i.e. $<0.03$ (Schouten et al., 2002; Kim

121 et al., 2008, 2010). The polar fractions of the selected samples were obtained as described

122 previously (Schouten et al., 2002; Kim et al., 2008, 2010) and analysed for their brGDGT

123 content. The small differences in extraction techniques and clean up procedures between the

124 sample sets are not expected to influence the GDGT distributions. Previous studies have shown 125 that the type of extraction method and extract processing have not a large effect on the GDGT 126 distributions (Schouten et al., 2007; Escala et al., 2009; Lengger et al., 2012) and that differences 127 remain within repeatability limits (Schouten et al., 2013b).

\subsection{GDGT analysis}

130 Samples were analysed for their GDGT content using High Performance Liquid

131 Chromatography / Atmospheric Pressure Chemical Ionization - Mass Spectrometry

132 (HPLC/APCI-MS) on an Agilent 1100 series instrument equipped with Chemstation software 133 according to Schouten et al. (2007). Separation of compounds was achieved on an analytical 134 Alltech Prevail Cyano column $(150 \mathrm{~mm} \times 2.1 \mathrm{~mm} ; 3 \mu \mathrm{m})$ held at a constant $30^{\circ} \mathrm{C}$ and using $n$ 135 hexane:iso-propanol 99:1 (v/v) as eluent, isocratically for the first $5 \mathrm{~min}$, then increasing to $1.8 \%$ 136 iso-propanol in 45 min. The column was rinsed in back flush mode with $10 \%$ iso-propanol in $n$ - 
137 hexane and re-equilibrated to starting conditions after each run. GDGTs were analysed in

138 Selective Ion Monitoring (SIM) mode as their $[\mathrm{M}+\mathrm{H}]^{+}$(protonated) derivatives. Relative

139 quantification of the GDGTs was based on peak areas in the $[\mathrm{M}+\mathrm{H}]^{+}$mass chromatograms. The

140 BIT index was used as defined by Hopmans et al. (2004):

141

$142 \quad B I T=\frac{[I a+I I a+I I I a]}{[I a+I I a+I I I a+I V]}$

143

144 The MBT' index was used as defined by Peterse et al. (2012) and differs from the original

145 definition (Weijers et al., 2007b) in the omission of GDGTs IIIb and IIIc:

146

$147 \quad M B T^{\prime}=\frac{[I a+I b+I c]}{[I a+I b+I c+I I a+I I b+I I c+I I I a]}$

148

149 The degree of cyclisation (DC) of brGDGTs was used as defined by Sinninghe Damsté et al.

150 (2009):

151

$152 \quad D C=\frac{[I b+I I b]}{[I a+I b+I I a+I I b]}$

153

154 The CBT ratio was used as defined by Weijers et al. (2007b):

155

$156 C B T=-\log \left(\frac{[I b+I I b]}{[I a+I I a]}\right)$

157 
Roman numerals refer to the structures given in Fig. 1.

\subsection{Statistical analysis}

An analysis of variance (ANOVA) was conducted on the DC and MBT' indices of different sample groups to determine whether or not these differ significantly from each other. The analysis was carried out by means of a pairwise multiple comparison test using Tamhane's T2 procedure, which assumes no equal variance between sample groups. Statistical analyses were conducted using the SPSS 21.0 software package (IBM corp.).

\section{Results and discussion}

\subsection{Atmospheric dust as a potential source for brGDGTs in the marine environment}

HPLC-MS analysis of the dust sampled along the African coast (Fig. 2) showed the presence of brGDGTs in all but one sample. However, none of the dust samples contained the full suite of brGDGTs, i.e. GDGTs IIIb and IIIc were not detected in any of the dust samples. Only in 5 out of the 13 dust samples all brGDGTs necessary for calculating a DC index and CBT ratio were present above detection level (Table 1). In a previous study, the analysis of two dust samples obtained from the same area as the dust filters analysed here did not yield any brGDGT signal (Hopmans et al., 2004), making the authors to suggest that brGDGTs are barely, if at all, transported by dust. The mass spectrometer in that analysis, however, was set to scan ions over the range $m / z 950$ to 1450 , i.e. in 'full scan' mode. The extracts of dust samples in the present study were run in the more sensitive Selective Ion Monitoring (SIM) mode, scanning only for the masses of interest, thereby increasing the sensitivity for GDGT detection by one to two orders of magnitude (cf. Schouten et al., 2007). This likely explains why at least some brGDGTs are now 
181 detected in dust and this implies that dust could be a potential source of brGDGTs in distal

182 marine sediments. This corroborates a recent publication by Fietz et al. (2013) that reports

183 brGDGTs in dust sampled off northwest Africa.

184 Backward trajectories for the dust samples used in our study have been computed previously

185 (Schefuß et al., 2003) and indicate that air masses sampled on the filters mostly originate from

186 the nearby African continent, especially from the Faya Largeau region in Chad. Therefore, it

187 could be assumed that the brGDGTs in the dust are derived from nearby African soils and thus

188 that their distributions, as expressed in the degrees of methylation and cyclisation (MBT' and

189 DC), should be similar to those of African soils. The average MBT' and DC indices for

190 brGDGTs in the dust samples are $0.80( \pm 0.06 ; n=8)$ and $0.11( \pm 0.04 ; n=5)$, respectively (Table

191 1). This falls within the range of African soils (from the soil database in Peterse et al., 2012), i.e.

$1920.76( \pm 0.22 ; \mathrm{n}=12)$ and $0.13( \pm 0.18 ; \mathrm{n}=16)$ for MBT' and DC, respectively, although the

193 variation in soils is larger (Fig. 3). Furthermore, the MBT' and DC indices of the dust are similar

194 to previously reported MBT' and DC indices of brGDGTs present in the surface sediments from

195 the Congo deep sea river fan (Weijers et al., 2007a), i.e. $0.72( \pm 0.10 ; n=7)$ and $0.15( \pm 0.08 ; n=7$,

196 Table 4, Fig. 3). This indeed suggests that brGDGTs found in the dust are ultimately derived

197 from soils on the adjacent African continent.

198 Notably, however, crenarchaeol was detected in all of the 13 dust samples and BIT indices

199 determined for the dust are substantially lower (average $0.25 \pm 0.08, \mathrm{n}=12$; Table 1 ) compared to

200 values generally found in soils, e.g. the average BIT index value in a compilation of global soil

201 data by Schouten et al. $(2013 a)$ is $0.90( \pm 0.14 ; n=224)$ with only a minority of soils having BIT

202 index values $<0.5$. Indeed, BIT indices for dust are also clearly lower than BIT indices for

203 African soils reported in Peterse et al. (2012), which are on average $0.81( \pm 0.21 ; n=16)$. The 
204 latter dataset only contains two soils with BIT $<0.50$ and none reaching as low as 0.25 . These

205 differences could be caused by two processes, i.e. selective degradation of GDGTs during 206 atmospheric transport or addition of crenarchaeol to dust. Selective degradation of brGDGTs

207 relative to crenarchaeol during atmospheric dust transport seems unlikely. Huguet et al. (2008)

208 have shown that in a turbidite deposit subject to prolonged oxygen exposure, crenarchaeol is

209 preferentially oxidized compared to brGDGTs. This was attributed, however, to the fact that the

210 terrigenous derived brGDGTs were likely protected via close association with clay minerals in

211 contrast to the marine-derived crenarchaeol. If derived from soils, crenarchaeol will be similarly

212 associated with dust particles as brGDGTs and therefore no selective degradation is expected.

213 Hence, there may be an additional source for crenarchaeol to explain the low BIT indices for

214 dust. One likely source for additional crenarchaeol on the dust filters is sea spray. Indeed,

215 analysis of the surface waters collected along the western African coast showed the clear

216 presence of crenarchaeol (Table 2) pointing to sea spray as a potential source of crenarchaeol. In

217 some of the surface waters brGDGTs were also detected, suggesting that sea spray may also be a

218 source for the brGDGTs on the dust filters. However, only the surface waters from the lower

219 salinity waters of the Congo River plume contain brGDGTs, likely delivered by the Congo River

220 (cf. Hopmans et al., 2004; Weijers et al., 2007a). In contrast, surface waters taken outside the

221 Congo River plume area barely contain brGDGTs, if at all (Table 2). Hence, the brGDGTs

222 detected in the dust, sampled outside areas of major river influence, are suggested to be

223 predominantly sourced by particles derived from the African continent. Notably, the dust

224 sampled off northwest Africa by Fietz et al. (2013) reflected BIT index values of 0.84 on

225 average. Although BIT index analyses between laboratories could differ substantially (Schouten

226 et al., 2013b), this still is a large difference. As yet it is difficult to explain this difference, but 
227 maybe the location of the dust samplers on the research vessel, i.e. their proximity to the sea

228 surface, and weather conditions, might play a role here.

\subsection{Sources of brGDGTs in distal marine sediments}

231 Transport of dust from the African continent to the equatorial Atlantic oceans is a well-known

232 phenomenon (e.g. Darwin, 1846; Chester et al., 1972; Prospero and Carlson, 1972) and for plant 233 wax derived long chain $n$-alkanes it has been shown that they can be delivered to the marine 234 realm via dust transport over distances of several thousand kilometres (e.g. Simoneit, 1977;

235 Gagosian et al., 1981; Schefuß et al., 2003; Bendle et al. 2007) and recently Fietz et al. (2013) 236 showed the presence of brGDGTs in dust far off northwest Africa. In order to see if also an 237 important contributor to the pool of brGDGTs in distal marine sediments, we compare 238 distributions of brGDGTs in both African soils and near shore dust with those in low latitude 239 Atlantic Ocean surface sediments (Table 3 and Fig. 2). Analysis shows that all Atlantic Ocean 240 surface sediments contained brGDGTs, though one sediment did not contain all brGDGTs in 241 sufficient amounts for calculating a DC index (Table 3). The MBT' index of these Atlantic 242 Ocean sediments is on average $0.28( \pm 0.10 ; n=9$, Table 5). This is significantly different $243(\mathrm{p}<0.001)$ from MBT’ indices of African soils and dust, i.e. $0.76( \pm 0.22, \mathrm{n}=16)$ and $0.80( \pm 0.06$, $244 \mathrm{n}=8$ ) on average, respectively (Tables 5 and 6). Although this could potentially indicate that 245 brGDGTs in these sediments are not derived from the warm African continent but derived from 246 higher and thus colder latitudes with lower MBT' values, this seems unlikely as Africa is the 247 major source of dust in the Atlantic Ocean (e.g. Schefuß et al., 2003 and references cited therein; 248 Fietz et al., 2013). When DC indices of African soils and dust are compared with those of low 249 latitude Atlantic surface sediments, a similar pattern emerges as for the MBT': DC indices of 

254 African dust.

255

equatorial Atlantic sediments are on average $0.39( \pm 0.16, n=8)$, which is significantly different $(\mathrm{p}<0.10)$ from that of African soils and dust, i.e. $0.13( \pm 0.18, \mathrm{n}=16)$ and $0.11( \pm 0.04, \mathrm{n}=5)$, respectively (Tables 5 and 6, Fig. 4). Collectively, these differences in distribution strongly suggest that brGDGTs in the low latitude Atlantic sediments are not primarily sourced by

In addition to the low-latitude Atlantic Ocean sediments, a set of 25 distal marine sediments from other locations were analysed for their brGDGT distribution (Table 3). Four additional open marine sediments characterised by a low BIT index (i.e. <0.08), and for which brGDGT composition was previously reported by Peterse et al. (2009) and Zhu et al. (2011), were added to the dataset as well to make a total of 38 marine sediments, including the low latitude Atlantic Ocean sediments. Out of these 38 sediments, 35 contained sufficient amounts of brGDGTs required for calculating a DC index (Table 3). The average value of the DC indices for these distal marine sediments is $0.40( \pm 0.16, n=35)$. This is similar to the average value as found for the low-latitude Atlantic sediments, but significantly different $(\mathrm{p}<0.10)$ from DC indices of global soils (Tables 5 and 6, Fig. 4). Thus, it can be concluded that also on a more global scale the distribution of brGDGTs in distal marine sediments is significantly different from the distribution of brGDGTs in terrigenous sources and, hence, that dust input is likely not a major source for them. The alternative explanation is that brGDGTs in open marine sediments are produced in-situ. For near coastal locations, in-situ production has been suggested previously by Peterse et al. (2009) and Zhu et al. (2011) and, interestingly, these studies reported distinctively high degrees of cyclisation (i.e. low CBT ratios) for marine sediments as well. Peterse et al. (2009) found that marine and fjord sediments around Svalbard were characterised by an average CBT ratio of $-0.27( \pm 0.09)$, which equals an average DC index of $0.65( \pm 0.03)$, much higher than 
273 the average DC index of Svalbard soils of $0.17( \pm 0.11)$. Zhu et al. (2011) found increased

274 brGDGT abundances normalised on TOC further away from the river mouth onto the shelf, 275 which is accompanied by a trend to higher DC indices (Fig. 5, based on data reported in Zhu et 276 al., 2011). In addition, brGDGTs have been reported in sediments at and near hydrothermal vents 277 along the Eastern Lau Spreading Center in the South Pacific Ocean (Hu et al., 2012) and two 278 types of brGDGTs have been reported in a carbonate chimney of Lost City Hydrothermal Field 279 near the mid-Atlantic Ridge (Lincoln et al., 2013). Notably, based on the data provided in Hu et 280 al. (2012), the brGDGTs in their sediment TVG8 are also characterised by a high degree of 281 cyclisation. Our results, together with those of Peterse et al. (2009) and Zhu et al. (2011), as well 282 as Hu et al. (2012) and Lincoln et al. (2013), form strong circumstantial evidence for the global 283 occurrence of in-situ production of brGDGTs in marine sediments. For soils and peat it has been 284 suggested that Acidobacteria might be the dominant producers of brGDGTs (Weijers et al., 285 2009a; Sinninghe Damsté et al., 2011). Although a microbial community producing brGDGTs in 286 the marine environment might be totally different from that in soils, Acidobacteria have indeed

287 been reported to be present in marine surface sediments as well as in hydrothermal chimneys 288 (Barns et al., 1999; Lopez-Garcia et al., 2003, Polymenakou et al., 2005; Li et al., 2009;

289 Brazelton et al., 2010).

290

\subsection{Exploring factors controlling the distribution of marine brGDGTs}

292 As discussed in section 3.2, brGDGTs present in open marine sediments are characterised by 293 relatively high DC and low CBT values. In soils the CBT ratio of brGDGTs is related to soil $\mathrm{pH}$ 294 (Weijers et al., 2007b; Peterse et al., 2010) with a higher degree of cyclisation (equals low CBT 295 ratios) corresponding to higher $\mathrm{pH}$ values. When the marine CBT values are translated to $\mathrm{pH}$ 
296 using the global soil calibration (Weijers et al., 2007b), reconstructed pH varies between 6.1 and

297 9.9. Although this includes the average ocean water $\mathrm{pH}$ of ca. 8, the variability is large in

298 comparison with the relatively small variation in sea water $\mathrm{pH}$. This large variation in DC indices

299 may indicate that the brGDGTs found in marine sediments are mainly produced within these

300 sediments, where $\mathrm{pH}$ values can rapidly change depending on redox conditions, rather than in the

301 marine water column. Unfortunately, no long term $\mathrm{pH}$ data are available for the core top

302 sediments used in this study to investigate the relation between the degree of cyclisation and

303 sediment $\mathrm{pH}$ in more detail.

304

\subsection{Implications for GDGT based proxies}

306 The production of brGDGTs in marine sediments may have consequences for some of the 307 GDGT-based proxies currently used. For example, the BIT index is used as indicator for the 308 relative amount of soil OM in marine sediments (Hopmans et al., 2004). Due to the relatively 309 small amounts of brGDGTs found in distal marine sediments the marine end-member of the BIT 310 index will be slightly higher than 0. Indeed, based on a data compilation, Schouten et al. (2013a) 311 found an average BIT index for open marine sediments of $0.04( \pm 0.03, n=278)$. However, as the

312 end-member distributions for soils $(0.90 \pm 0.14, \mathrm{n}=224$; Schouten et al. 2013a $)$ and marine

313 sediments are still substantially different, marine in-situ produced brGDGTs will not

314 substantially influence the use of the BIT index in marine sediments as indicator of soil derived 315 OM.

316 The MBT'-CBT proxy is used to estimate past continental air temperatures based on the 317 distribution of soil-derived brGDGTs (Weijers et al., 2007b; Peterse et al., 2012). It is applied in 318 marine sediments that receive substantial soil OM input, and thus characterised by a high BIT 
319 index, preferably near river outflows in order to obtain river-basin integrated signals (Weijers et

320 al., 2007a). This study shows that at low BIT indices, the MBT' index and CBT ratio become

321 skewed by the ostensibly marine in-situ produced brGDGTs and, therefore, render the MBT'-

322 CBT proxy unsuitable. Sites characterised by low BIT indices not only include distal marine

323 settings but also coastal settings removed from any fluvial OM input. In our dataset of Congo

324 deep sea river fan sediments, one location with a low BIT index of 0.05 (T89-14) yields a DC

325 index clearly higher (and consequently a CBT ratio clearly lower) than the other Congo deep sea

326 fan sediments that are characterised by a higher BIT index (Table 4). In the East China Sea

327 dataset of Zhu et al. (2011) the sediments with elevated DC indices, i.e. >0.35 (Fig. 5) have an

328 average BIT index of $0.09( \pm 0.02, n=12)$. Based on these data, therefore, a BIT index threshold

329 of >0.1 seems appropriate for MBT'-CBT applications. It needs to be emphasized, however, that

330 at other locations this threshold might be somewhat higher, for example due to lower

331 crenarchaeol production. Although a previous interlaboratory study highlighted concerns

332 regarding the reproducibility of the BIT index between laboratories and instruments (Schouten et

333 al., 2009), a recent and more extensive interlaboratory comparison showed that low BIT indices

334 (i.e. $<0.1)$ can be reproduced relatively precisely between laboratories (Schouten et al., 2013b).

335 Since variations in terrigenous soil OM input also occur over time, down core MBT'-CBT

336 applications should always be accompanied with a BIT index record.

\section{Conclusions}

339 Our study shows that brGDGTs are present in dust, albeit in low abundance. Distributions of 340 dust-derived brGDGTs are similar to those of soils but clearly different from those of distal 341 marine sediments. Thus, although dust input to open ocean settings might occur, it does not seem 
342 to be an important source of brGDGTs in distal marine settings. Branched GDGT distributions in

343 distal marine sediments are characterised by a distinctive high DC index. This strongly suggests

344 in-situ production of brGDGTs in distal marine sediments on a global scale, and supports earlier

345 reports of potential in-situ production in near coastal marine sediments (Peterse et al., 2009; Zhu

346 et al., 2011). Based on the large variability of DC indices in marine sediments, it is suggested

347 that marine derived brGDGTs are mainly produced in-situ in the sediments rather than the

348 overlying water column. The magnitude of in-situ production of brGDGTs is low compared to

349 pelagic marine crenarchaeol production and, therefore, not notably influencing the use of the BIT

350 index as proxy for relative soil OM input in marine sediments. However, the MBT'-CBT proxy

351 for continental temperatures will be biased by in-situ produced brGDGTs when the overall

352 abundance of brGDGTs is low, i.e. at low BIT indices (based on data in this study <0.1). It

353 should therefore only be applied to settings known to receive substantial soil OM input.

355 Acknowledgements

356 The authors wish to thank Chun Zhu and Francien Peterse for sharing GDGT data from the East

357 China Sea and the global soil dataset. Gert-Jan Reichart is thanked for helpful discussion. We

358 thank the Captain and crew of R/V Meteor for enabling the seawater sampling during M56. Two

359 anonymous reviewers and the editor are thanked for their comments which helped to improve

360 this manuscript. The work leading to these results has received partial funding from the

361 European Research Council under the European Union's Seventh Framework Programme

362 (FP/2007-2013) / ERC Grant Agreement nr. 226600 to J.S.S.D. and nr. 306390 to J.W.H.W..

363 Both J.W.H.W. and S.S. thank the Netherlands Organisation for Scientific Research (NWO) for

364 funding through a Veni and Vici grant, respectively. 


\section{References}

Bannert, A., Mueller-Niggemann, C., Kleineidam, K., Wissing, L., Cao, Z.H., Schwark, L., Schloter, M., 2011. Comparison of lipid biomarker and gene abundance characterizing the archaeal ammonia-oxidizing community in flooded soils. Biology and Fertility of Soils 47, 839-843.

Barns, S.M., Takala, S.L., Kuske, C.R., 1999. Wide distribution and diversity of members of the bacterial Kingdom Acidobacterium in the environment. Applied and Environmental Microbiology 65, 1731-1737.

Bendle, J., Kawamura, K., Yamazaki, K., Niwai, T., 2007. Latitudinal distribution of terrestrial lipid biomarkers and $n$-alkane compound-specific stable carbon isotope ratios in the atmosphere over the western Pacific and Southern Ocean. Geochimica et Cosmochimica Acta 71, 5934-5955.

Brazelton, W.J., Ludwig, K.A., Sogin, M.L., Andreishcheva, E.N., Kelley, D.S., Shen, C.-C, Edwards, R.L., Baross, J.A., 2010. Archaea and bacteria with surprising microdiversity show shifts in dominance over 1,000-year time scales in hydrothermal chimneys. Proceedings of the National Academy of Sciences of the USA 107, 1612-1617.

Chester, R., Elderfield, H., Griffin, J.J., Johnson, L.R., Padgham, R.C., 1972. Eolian dust along the eastern margins of the Atlantic Ocean. Marine Geology 13, 91-105.

Darwin, C., 1846. An account of the fine dust which often falls on vessels in the Atlantic Ocean. Quarterly Journal of the Geological Society 2, 26-30.

De Jonge, C., Hopmans, E.C., Stadnitskaia, A., Rijpstra, W.I.C., Hofland, R., Tegelaar, E., Sinninghe Damsté, J.S., 2013. Identification of novel penta- and hexamethylated branched glycerol dialkyl glycerol tetraethers in peat using HPLC-MS ${ }^{2}$, GC-MS and GC-SMB-MS. Organic Geochemistry 54, 78-82.

Eglinton, G., Gonzalez, A.G., Hamilton, R.J., Raphael, R.A., 1962. Hydrocarbon constituents of the wax coatings of plant leaves - a taxonomic survey. Phytochemistry 1, 89-102.

Escala, M., Fietz, S., Rueda, G., Rosell-Melé, A., 2009. Analytical considerations for the use of the paleothermometer Tetraether Index 86 and the branched vs isoprenoid tetraether index regarding the choice of cleanup and instrumental condtions. Analytical Chemistry 81, 27012707.

Fietz, S., Prahl, F.G., Moraleda, N., Rosell-Melé, A., 2013. Eolian transport of glycerol dialkyl glycerol tetraethers (GDGTs) off northwest Africa. Organic Geochemisry 64, 112-118.

Gagosian, R.B., Peltzer, E.T., Zafiriou, O.C., 1981. Atmospheric transport of continentally derived lipids to the tropical north Pacific. Nature 291, 312-315.

Goñi, M.A., Ruttenberg, K.C., Eglinton, T.I., 1997. Source and contribution of terrigenous organic carbon to surface sediments in the Gulf of Mexico. Nature 389, 275-278. 
Hedges, J.I., Keil, R.G., Benner, R., 1997. What happens to terrestrial organic matter in the ocean? Organic Geochemistry 27, 195-212.

Herfort, L., Schouten, S., Boon, J.P., Woltering, M., Baas, M., Weijers, J.W.H., Sinninghe Damsté, J.S., 2006. Characterization of transport and deposition of terrestrial organic matter in the southern North Sea using the BIT index. Limnology and Oceanography 51, 2196-2205.

Hopmans, E.C., Weijers, J.W.H., Schefuß, E., Herfort, L., Sinninghe Damsté, J.S., Schouten, S., 2004. A novel proxy for terrestrial organic matter in sediments based on branched and isoprenoid tetraether lipids. Earth and Planetary Science Letters 224, 107-116.

Hu, J., Meyers, P.A., Chen, G., Peng, P., Yang, Q., 2012. Archaeal and bacterial glycerol dialkyl glycerol tetraethers in sediments from the Eastern Lau Spreading Center, South Pacific Ocean. Organic Geochemistry 43, 162-167.

Huguet, C., de Lange, G.J., Gustafsson, Ö., Middelburg, J.J., Sinninghe Damsté, J.S., Schouten, S., 2008. Selective preservation of soil organic matter in oxidezed marine sediments (Madeira Abyssal Plain). Geochimica et Cosmochimica Acta 72, 6061-6068.

Huguet, C., Smittenberg, R.H., Boer, W., Sinninghe Damsté, J.S., Schouten, S., 2007. Twentieth century proxy records of temperature and soil organic matter input in the Drammensfjord, southern Norway. Organic Geochemistry 38, 1838-1849.

Killops, S.D., Frewin, N.L., 1994. Triterpenoid diagenesis and cuticular preservation. Organic Geochemistry 21, 1193-1209.

Kim, J.-H., Schouten, S., Hopmans, E.C., Donner, B., Sinninghe Damsté, J.S., 2008. Global sediment core-top calibration of the TEX86 paleothermometer in the ocean. Geochimica et Cosmochimica Acta 72, 1154-1173.

Kim, J.-H., van der Meer, J., Schouten, S., Helmke, P., Willmott, V., Sangiorgi, F., Koc, N., Hopmans, E.C., Sinninghe Damsté, J.S., 2010. New indices and calibrations derived from the distribution of crenarchaeal isoprenoid tetraether lipids: Implications for past sea surface temperature reconstructions. Geochimica et Cosmochimica Acta 74, 4639-4654.

Kim, J.-H., Buscail, R., Bourrin, F., Palanques, A., Sinninghe Damsté, J.S., Bonnin, J., Schouten, S., 2009. Transport and depositional process of soil organic matter during wet and dry storms on the Têt inner shelf (NW Mediterranean). Palaeogeography, Palaeoclimatology, Palaeoecology 273, 228-238.

Kim, J.-H., Schouten, S., Buscail, R., Ludwig, W., Bonnin, J., Sinninghe Damsté, J.S., Bourrin, F., 2006. Origin and distribution of terrestrial organic matter in the NW Mediterranean (Gulf of Lion): application of the newly developed BIT index. Geochemistry, Geophysics, Geosystems 7, Q11017-doi:10.1029/2006GC001306.

Leininger, S., Urich, T., Schloter, M., Schwark, L., Qi, J., Nicol, G.W., Prosser, J.I., Schuster, S. C., Schleper, C., 2006. Archaea predominate among ammonia-oxidizing prokaryotes in soils. Nature 442, 806-809. 
Lengger, S.K., Hopmans E.C., Sinninghe Damsté, J.S., Schouten, S., 2012. A comparison of extraction and work-up techniques for analysis of core- and intact polar tetraether lipids from sedimentary environments. Organic Geochemistry 47, 34-40.

Li, H., Yu, Y., Luo, W., Zeng, Y., Chen, B., 2009. Bacterial diversity in surface sediments from the Pacific Arctic Ocean. Extremophiles 13, 233-246.

Lincoln, S.A., Bradley, A.S., Newman, S.A., Summons, R.E., 2013. Archaeal and bacterial glycerol dialkyl glycerol tetraether lipids in chimneys of the Lost City Hydrothermal Field. Organic Geochemistry 60, 45-53.

López-García, P., Duperron, S., Philippot, P., Foriel, J., Susini, J., Moreira, D., 2003. Bacterial diversity in hydrothermal sediment and epsilonproteobacterial dominance in experimental microcolonizers at the Mid-Atlantic Ridge. Environmental Microbiology 5, 961-976.

Peterse, F., Kim, J.-H., Schouten, S., Klitgaard Kristensen, D., Koç, N., Sinninghe Damsté, J.S., 2009. Constraints on the application of the MBT/CBT palaeothermometer at high latitude environments (Svalbard, Norway). Organic Geochemistry 40, 692-699.

Peterse, F., Nicol, G.W., Schouten, S., Sinninghe Damsté, J.S., 2010. Influence of soil pH on the abundance and distribution of core and intact polar lipid-derived branched GDGTs in soil. Organic Geochemistry 41, 1171-1175.

Peterse, F., van der Meer, J., Schouten, S., Weijers, J.W.H., Fierer, N., Jackson, R.B., Kim, J.-H., Sinninghe Damsté, J.S., 2012. Revised calibration of the MBT-CBT paleotemperature proxy based on branched tetraether membrane lipids in surface soils. Geochimica et Cosmochimica Acta 96, 215-229.

Polymenakou, P.N., Bertilsson, S., Tselepides, A., Stephanou, E.G., 2005. Bacterial community composition in different sediments from the Eastern Mediterranean Sea: a comparison of four 16S ribosomal DNA clone libraries. Microbial Ecology 50, 447-462.

Powers, L.A., Werne, J.P., Johnson, T.C., Hopmans, E.C., Sinninghe Damsté, J.S., Schouten, S., 2004. Crenarchaeotal membrane lipids in lake sediments: A new paleotemperature proxy for continental paleoclimate reconstruction? Geology 32, 613-616.

Prospero, J.M., Carlson, T.N., 1972. Vertical and areal distribution of Saharan dust over the western equatorial North Atlantic Ocean. Journal of Geophysical Research 77, 5255-5265.

Schefuß, E., Ratmeyer, V., Stuut, J.-B.W., Jansen, J.H.F., and Sinninghe Damsté, J.S., 2003. Carbon isotope analyses of n-alkanes in dust from the lower atmosphere over the central eastern Atlantic. Geochimica et Cosmochimica Acta 67, 1757-1767.

Schefuß, E., Versteegh, G.J.M., Jansen, J.H.F., Sinninghe Damsté, J.S., 2004. Lipid biomarkers as major source and preservation indicators in SE Atlantic surface sediments. Deep-Sea Research I 51, 1199-1228. 
Schouten, S., Hopmans, E.C., Sinninghe Damsté, J.S., 2013a. The organic geochemistry of glycerol dialkyl glycerol tetraether lipids: A review. Organic Geochemistry 54, 19-61.

Schouten, S., Hopmans, E.C., Rosell-Melé, A., Pearson, A., Adam, P., Bauersachs, T., Bard, E., Bernasconi, S.M., Bianchi, T.S., Brocks, J.J., Carlson, L.T., Castañeda, I.S., Derenne, S., Dogrul Selver, A., Dutta, K., Eglinton, T., Fosse, C., Galy, V., Grice, K., Hinrichs, K.-U., Huang, Y., Huguet, A., Huguet, C., Hurley, S., Ingalls, A., Jia, G., Keely, B., Knappy, C., Kondo, M., Krishnan, S., Lincoln, S., Lipp, J., Mangelsdorf, K., Martínez-García, A., van der Meer, J., Ménot, G., Mets, A., Mollenhauer, G., Ohkouchi, N., Ossebaar, J., Pagani, M., Pancost, R.D., Pearson, E.J., Peterse, F., Reichart, G.-J., Schaeffer, P., Schmitt, G., Schwark, L., Shah, S.R., Smith, R.W., Smittenberg, R.H., Takano, Y., Talbot, H.M., Taylor, K.W.R., Tarazo, R., van Dongen, B.E., Van mooy, B.A.S., Wang, J., Warren, C., Weijers, J.W.H., Werne, J.P., Woltering, M., Xie, S., Yamamoto, M., Yang, H., Zhang, C.L., Zhang, Y., Zhao, M., Sinninghe Damsté, J.S., 2013b. An interlaboratory study of TEX86 and BIT analysis of sediments, extracts and standard mixtures. Geochemistry, Geophysics, Geosystems 14, 52635285 .

Schouten, S., Hopmans, E.C., Schefuß, E., Sinninghe Damsté, J.S., 2002. Distributional variations in marine crenarchaeotal membrane lipids: a new tool for reconstructing ancient sea water temperatures? Earth and Planetary Science Letters 204, 265-274.

Schouten, S., Hopmans, E.C., van der Meer, J., Mets, A., Bard, E., Bianchi, T.S., Diefendorf, A., Escala, M., Freeman, K.H., Furukawa, Y., Huguet, C., Ingalls, A., Ménot-Combes, G., Nederbragt, A.J., Oba, M., Pearson, A., Pearson, E.J., Rosell-Melé, A., Schaeffer, P., Shah, S.R., Shanahan, T.M., Smith, R.W., Smittenberg, R.H., Talbot, H.M., Uchida, M., Van mooy, B.A.S., Yamamoto, M., Zhang, Z., Sinninghe Damsté, J.S., 2009. An interlaboratory study of TEX $_{86}$ and BIT analysis using high-performance liquid chromatography-mass spectrometry. Geochemistry, Geophysics, Geosystems 10, Q03012, doi: 10.1029/2008GC002221.

Schouten, S., Huguet, C., Hopmans, E.C., Kienhuis, M.V.M., Sinninghe Damsté, J.S., 2007. Analytical methodology for TEX86 paleothermometry by high-performance liquid chromatography/atmospheric pressure chemical ionization-mass spectrometry. Analytical Chemistry 79, 2940-2944.

Simoneit, B.R.T., 1977. Organic matter in eolian dusts over the Atlantic Ocean. Marine Chemistry 5, 443-464.

Sinninghe Damsté, J.S., Hopmans, E.C., Pancost, R.D., Schouten, S., Geenevasen, J.A.J., 2000. Newly discovered non-isoprenoid glycerol dialkyl glycerol tetraether lipids in sediments. Chemical Communications 1683-1684.

Sinninghe Damsté, J.S., Ossebaar, J., Abbas, B., Schouten, S., Verschuren, D., 2009. Fluxes and distribution of tetraether lipids in an equatorial African lake: Constraints on the application of the TEX 86 palaeothermometer and BIT index in lacustrine settings. Geochimica et Cosmochimica Acta 73, 4232-4249.

Sinninghe Damsté, J.S., Rijpstra, W.I.C., Hopmans, E.C., Weijers, J.W.H., Foesel, B.U., Overmann, J., Dedysh, S.N., 2011. 13,16-Dimethyl octacosanedioic acid (iso-diabolic acid), a 
common membrane-spanning lipid of acidobacteria subdivisions 1 and 3. Applied and Environmental Microbiology 77, 4147-4154.

Sinninghe Damsté, J.S., Schouten, S., Hopmans, E.C., van Duin, A.C.T., Geenevasen, J.A.J., 2002. Crenarchaeol: the characteristic core glycerol dibiphytanyl glycerol tetraether membrane lipid of cosmopolitan pelagic crenarchaeota. Journal of Lipid Research 43, 16411651.

Smith, R.W., Bianchi, T.S., Li, X., 2012. A re-evaluation of the use of branched GDGTs as terrestrial biomarkers: Implications for the BIT Index. Geochimica et Cosmochimica Acta 80, 14-29.

Spiess, V., Cruise Participants, 2008. Report and preliminary results of METEOR cruise M56, Douala - Cape Town, 20 November - 29 December 2002. METEOR - Berichte 08-1, Fachbereich Geowissenschaften, Universität Bremen, p.66.

Versteegh, G.J.M., Schefuß, E., Dupont, L., Marret, F., Sinninghe Damsté, J.S., Jansen, J.H.F. 2004. Taraxerol and Rhizophora pollen as proxies for tracking past mangrove ecosystems. Geochimica et Cosmochimica Acta 68, 411-422.

Walsh, E.M., Ingalls, A.E., Keil, R.G., 2008. Sources and transport of terrestrial organic matter in Vancouver Island fjords and the Vancouver-Washinghton Margin: A multiproxy approach using $\delta^{13} \mathrm{C}_{\text {org }}$, lignin phenols, and the ether lipid BIT index. Limnology and Oceanograophy 53, 1054-1063.

Weijers, J.W.H., Panoto, E., Van Bleijswijk, J., Schouten, S., Rijpstra, W.I.C., Balk, M., Stams, A.J.M., Sinninghe Damsté, J.S., 2009a. Constraints on the biological source(s) of the orphan branched tetraether membrane lipids. Geomicrobiology Journal 26, 402-414.

Weijers, J.W.H., Schefuß, E., Schouten, S., Sinninghe Damsté, J.S., 2007a. Coupled thermal and hydrological evolution of tropical Africa over the last deglaciation. Science 315, 1701-1704.

Weijers, J.W.H., Schouten, S., Hopmans, E.C., Geenevasen, J.A.J., David, O.R.P., Coleman, J.M., Pancost, R.D., Sinninghe Damsté, J.S., 2006a. Membrane lipids of mesophilic anaerobic bacteria thriving in peats have typical archaeal traits. Environmental Microbiology 8, 648657.

Weijers, J.W.H., Schouten, S., Schefuß, E., Schneider, R.R., Sinninghe Damsté, J.S., $2009 b$. Disentangling marine, soil and plant organic carbon contributions to continental margin sediments: A multi-proxy approach in a 20,000 year sediment record from the Congo deepsea fan. Geochimica et Cosmochimica Acta 73, 119-132.

Weijers, J.W.H., Schouten, S., Spaargaren, O.C., Sinninghe Damsté, J.S., 2006b. Occurrence and distribution of tetraether membrane lipids in soils: Implications for the use of the TEX 86 proxy and the BIT index. Organic Geochemistry 37, 1680-1693. 
Weijers, J.W.H., Schouten, S., van den Donker, J.C., Hopmans, E.C., Sinninghe Damsté, J.S., 2007b. Environmental controls on bacterial tetraether membrane lipid distribution in soils. Geochimica et Cosmochimica Acta 71, 703-713.

Weijers, J.W.H., Schouten, S., van der Linden, M., van Geel, B., Sinninghe Damsté, J.S., 2004. Water table related variations in the abundance of intact archaeal membrane lipids in a Swedish peat bog. FEMS Microbiology Letters 239, 51-56.

Zell, C., Kim, J.-H., Moreira-Turcq, P., Abril, G., Hopmans, E.C., Bonnet, M.-P., Lima Sobrinho, R., Sinninghe Damsté, J.S., 2013. Disentangling the origins of branched tetraether lipids and crenarchaeol in the lower Amazon River: Implications for GDGT-based proxies. Limnology and Oceanography 58, 343-353.

Zhu, C., Weijers, J.W.H., Wagner, T., Pan, J.-M., Chen, J.-F., Pancost, R.D., 2011. Sources and distributions of tetraether lipids in surface sediments across a large river-dominated continental margin. Organic Geochemistry 42, 376-386. 


\section{Tables}

Table 1: Fractional abundances and indices of brGDGTs and crenarchaeol present in dust sampled along the west coast of equatorial Africa. Roman numerals refer to the GDGT structures in Fig. 1, where IV is crenarchaeol; 'b.d.' = below detection limit; '-' indicates that the respective indices are not calculated due to absence of GDGTs.

\begin{tabular}{|c|c|c|c|c|c|c|c|c|c|c|c|c|c|c|}
\hline \multirow{2}{*}{ Dust sample } & \multirow{2}{*}{ Latitude } & \multirow{2}{*}{ Longitude } & \multicolumn{8}{|c|}{ GDGT fractional abundance } & \multirow{2}{*}{ BIT } & \multirow[b]{2}{*}{ MBT' } & \multirow[b]{2}{*}{ DC } & \multirow{2}{*}{ CBT } \\
\hline & & & $f(\mathbf{l a})$ & $f(\mathrm{lb})$ & $f($ Ic) & $f$ (Ila) & $f(\mathrm{Ilb})$ & $f($ IIc) & $f($ IIIa $)$ & $f(\mathrm{IV})$ & & & & \\
\hline D013 & $1.30 \mathrm{~N}$ & $6.94 \mathrm{~W}$ & 0.186 & 0.014 & 0.018 & 0.037 & b.d. & b.d. & 0.012 & 0.733 & 0.24 & 0.82 & - & - \\
\hline D014 & $1.32 \mathrm{~N}$ & $2.86 \mathrm{~W}$ & 0.152 & b.d. & b.d. & b.d. & b.d. & b.d. & b.d. & 0.848 & 0.15 & 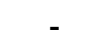 & - & . \\
\hline D015 & $1.52 \mathrm{~N}$ & $0.60 \mathrm{~W}$ & 0.195 & 0.017 & b.d. & 0.036 & 0.015 & b.d. & 0.015 & 0.722 & 0.25 & 0.76 & 0.12 & 0.86 \\
\hline D016 & $1.76 \mathrm{~N}$ & $1.64 \mathrm{E}$ & 0.207 & b.d. & b.d. & b.d. & b.d. & b.d. & b.d. & 0.793 & 0.21 & - & - & - \\
\hline DO17 & $2.61 \mathrm{~N}$ & $6.54 \mathrm{E}$ & 0.249 & 0.039 & b.d. & 0.067 & 0.020 & b.d. & b.d. & 0.625 & 0.34 & 0.77 & 0.16 & 0.73 \\
\hline D018 & $1.68 \mathrm{~N}$ & $7.97 \mathrm{E}$ & 0.153 & b.d. & b.d. & 0.063 & b.d. & b.d. & b.d. & 0.784 & 0.22 & 0.71 & - & - \\
\hline D019 & $1.74 \mathrm{~N}$ & $9.14 \mathrm{E}$ & 0.309 & 0.025 & b.d. & 0.062 & 0.017 & b.d. & b.d. & 0.587 & 0.39 & 0.81 & 0.10 & 0.95 \\
\hline DO20 & $1.65 \mathrm{~N}$ & $9.11 \mathrm{E}$ & 0.229 & b.d. & b.d. & b.d. & b.d. & b.d. & b.d. & 0.771 & 0.23 & - & - & - \\
\hline DO21 & $1.38 \mathrm{~S}$ & $8.54 \mathrm{E}$ & 0.173 & 0.010 & 0.004 & 0.018 & 0.008 & 0.002 & 0.009 & 0.777 & 0.20 & 0.84 & 0.08 & 1.04 \\
\hline DO22 & $2.91 \mathrm{~S}$ & $9.21 \mathrm{E}$ & 0.219 & b.d. & b.d. & b.d. & b.d. & b.d. & b.d. & 0.781 & 0.22 & - & - & - \\
\hline $\mathrm{DO} 23$ & $6.18 \mathrm{~S}$ & $10.05 \mathrm{E}$ & 0.368 & 0.018 & 0.006 & 0.027 & 0.009 & b.d. & 0.007 & 0.565 & 0.42 & 0.90 & 0.06 & 1.16 \\
\hline DO24 & $8.00 \mathrm{~S}$ & $11.86 \mathrm{E}$ & b.d. & b.d. & b.d. & b.d. & b.d. & b.d. & b.d. & 1.000 & - & - & - & - \\
\hline DO25 & $10.69 \mathrm{~S}$ & $12.50 \mathrm{E}$ & 0.138 & 0.029 & b.d. & 0.039 & b.d. & b.d. & b.d. & 0.794 & 0.18 & 0.81 & - & - \\
\hline
\end{tabular}


Table 2: Fractional abundances and indices of brGDGTs and crenarchaeol present in SPM of surface waters of the Atlantic Ocean along the west coast of equatorial Africa. Volume indicates the amount of water filtered for analysis; roman numerals refer to the GDGT structures in Fig. 1; 'b.d.' = below detection limit; '-' indicates that the respective indices are not calculated due to absence of GDGTs.

\begin{tabular}{|c|c|c|c|c|c|c|c|c|c|c|c|c|c|c|c|c|c|}
\hline \multirow{2}{*}{$\begin{array}{c}\text { SPM } \\
\text { sample }\end{array}$} & \multirow{2}{*}{$\begin{array}{l}\text { Lati- } \\
\text { tude }\end{array}$} & \multirow{2}{*}{$\begin{array}{l}\text { Longi- } \\
\text { tude }\end{array}$} & \multirow[b]{2}{*}{$\begin{array}{c}\text { Volume } \\
\text { (L) }\end{array}$} & \multirow{2}{*}{$\begin{array}{c}\text { Tempe- } \\
\text { rature } \\
\left({ }^{\circ} \mathrm{C}\right)\end{array}$} & \multirow{2}{*}{$\begin{array}{c}\text { Salinity } \\
(\% 0)\end{array}$} & \multicolumn{8}{|c|}{ GDGT fractional abundance } & \multirow[b]{2}{*}{ BIT } & \multirow[b]{2}{*}{ MBT' } & \multirow[b]{2}{*}{ DC } & \multirow[b]{2}{*}{ CB1 } \\
\hline & & & & & & $f($ la) & $f(\mathrm{lb})$ & $f(I c)$ & $f($ Ila) & $f(\mathrm{IIb})$ & $f(\mathrm{IIC})$ & $f($ IIIa) & $f(I V)$ & & & & \\
\hline M56B 2 & $3.77 \mathrm{~S}$ & $9.12 \mathrm{E}$ & 304 & 27.3 & 32.0 & 0.302 & 0.021 & 0.010 & 0.037 & 0.003 & b.d. & 0.004 & 0.623 & 0.38 & 0.88 & 0.07 & 1.14 \\
\hline M56B 23 & $4.81 \mathrm{~S}$ & $9.91 \mathrm{E}$ & 244 & 28.1 & 33.5 & 0.233 & 0.025 & 0.014 & 0.027 & 0.003 & b.d. & b.d. & 0.698 & 0.30 & 0.90 & 0.10 & 0.97 \\
\hline M56B 34 & $6.28 \mathrm{~S}$ & $10.47 \mathrm{E}$ & 403 & 27.6 & 28.0 & 0.551 & 0.012 & 0.005 & 0.069 & 0.003 & b.d. & 0.006 & 0.353 & 0.65 & 0.88 & 0.02 & 1.60 \\
\hline M56B 37 & $9.90 \mathrm{~S}$ & $10.87 \mathrm{E}$ & 304 & 27.0 & 36.0 & 0.389 & b.d. & b.d. & 0.044 & b.d. & b.d. & 0.018 & 0.549 & 0.45 & - & - & - \\
\hline M56B 43 & $15.40 \mathrm{~S}$ & $11.30 \mathrm{E}$ & 244 & 21.6 & 36.0 & 0.027 & b.d. & b.d. & b.d. & b.d. & b.d. & b.d. & 0.973 & 0.03 & - & - & - \\
\hline M56B 47 & $18.23 \mathrm{~S}$ & $11.58 \mathrm{E}$ & 111 & 16.0 & 35.3 & 0.002 & 0.000 & b.d. & 0.002 & b.d. & b.d. & 0.001 & 0.995 & 0.00 & - & - & - \\
\hline M56B 53 & $22.99 \mathrm{~S}$ & $13.17 \mathrm{E}$ & 198 & 18.5 & 35.3 & 0.005 & b.d. & b.d. & b.d. & b.d. & b.d. & b.d. & 0.995 & 0.01 & - & - & - \\
\hline M56B 57 & $26.10 \mathrm{~S}$ & 14.12 E & 113 & 16.2 & 35.3 & 0.001 & b.d. & b.d. & b.d. & b.d. & b.d. & b.d. & 0.999 & 0.00 & - & - & - \\
\hline
\end{tabular}


Table 3: Fractional abundances and indices of brGDGTs present in distal marine surface sediments. Roman numerals refer to the

GDGT structures in Fig. 1; 'b.d.' = below detection limit; '-' indicates that the respective indices are not calculated due to absence of GDGTs. Asterisks indicate sediments included in the 'equatorial Atlantic' subgroup of marine sediments (cf. Figs. 3 and 4 ).

\begin{tabular}{|c|c|c|c|c|c|c|c|c|c|c|c|c|c|c|c|}
\hline \multirow[b]{2}{*}{$\begin{array}{l}\text { Sediment } \\
\text { sample }\end{array}$} & \multirow[b]{2}{*}{ Ocean/Region } & \multirow[b]{2}{*}{ Latitude } & \multirow[b]{2}{*}{ Longitude } & \multirow{2}{*}{$\begin{array}{l}\text { Water } \\
\text { depth } \\
\text { (m) }\end{array}$} & \multicolumn{7}{|c|}{ GDGT fractional abundance } & \multirow[b]{2}{*}{ BIT } & \multirow[b]{2}{*}{ MBT' } & \multirow[b]{2}{*}{ DC } & \multirow[b]{2}{*}{ CBT } \\
\hline & & & & & $f($ la) & $f(\mathrm{lb})$ & $f(I C)$ & $f(\mathrm{lla})$ & $f(\mathrm{llb})$ & f(IIc) & $f($ IIIa) & & & & \\
\hline GeoB2212-1 & Atlantic Ocean* & $4.03 \mathrm{~N}$ & $25.62 \mathrm{~W}$ & 5521 & 0.227 & b.d. & b.d. & 0.144 & b.d. & b.d. & 0.629 & 0.06 & 0.23 & - & - \\
\hline GeoB2213-1 & Atlantic Ocean* & $1.27 \mathrm{~N}$ & $24.15 \mathrm{~W}$ & 4323 & 0.150 & 0.017 & b.d. & 0.135 & 0.040 & b.d. & 0.658 & 0.01 & 0.17 & 0.17 & 0.70 \\
\hline GeoB2707-4 & Atlantic Ocean & $41.95 \mathrm{~S}$ & $56.32 \mathrm{~W}$ & 3167 & 0.377 & 0.077 & 0.035 & 0.158 & 0.228 & 0.071 & 0.054 & 0.01 & 0.49 & 0.36 & 0.25 \\
\hline GeoB2722-2 & Atlantic Ocean & $47.33 \mathrm{~S}$ & $58.62 \mathrm{~W}$ & 2351 & 0.091 & 0.103 & 0.037 & 0.123 & 0.454 & 0.143 & 0.049 & 0.00 & 0.23 & 0.72 & -0.41 \\
\hline GeoB2723-2 & Atlantic Ocean & $48.91 \mathrm{~S}$ & $57.88 \mathrm{~W}$ & 569 & 0.246 & 0.104 & 0.049 & 0.129 & 0.322 & 0.077 & 0.073 & 0.02 & 0.40 & 0.53 & -0.06 \\
\hline GeoB2806-6 & Atlantic Ocean & $37.83 \mathrm{~S}$ & $53.14 \mathrm{~W}$ & 3542 & 0.159 & 0.160 & 0.073 & 0.149 & 0.292 & 0.079 & 0.089 & 0.01 & 0.39 & 0.59 & -0.17 \\
\hline GeoB2809-2 & Atlantic Ocean & $36.33 \mathrm{~S}$ & $51.52 \mathrm{~W}$ & 3539 & 0.194 & 0.160 & 0.072 & 0.161 & 0.260 & 0.068 & 0.084 & 0.02 & 0.43 & 0.54 & -0.07 \\
\hline GeoB2824-1 & Atlantic Ocean & $33.50 \mathrm{~S}$ & $42.50 \mathrm{~W}$ & 4512 & 0.172 & 0.065 & 0.030 & 0.161 & 0.115 & 0.029 & 0.428 & 0.01 & 0.27 & 0.35 & 0.27 \\
\hline GeoB6407-2 & Atlantic Ocean & $42.04 \mathrm{~S}$ & $19.50 \mathrm{~W}$ & 3384 & 0.147 & 0.026 & 0.010 & 0.143 & 0.135 & 0.035 & 0.505 & 0.01 & 0.18 & 0.36 & 0.26 \\
\hline GeoB6410-1 & Atlantic Ocean & $44.52 \mathrm{~S}$ & $20.90 \mathrm{~W}$ & 4038 & 0.132 & 0.028 & 0.012 & 0.108 & 0.103 & 0.029 & 0.588 & 0.01 & 0.17 & 0.35 & 0.26 \\
\hline GeoB8303-5 & Atlantic Ocean* & $34.26 \mathrm{~S}$ & $16.78 \mathrm{E}$ & 3447 & 0.134 & 0.131 & 0.068 & 0.145 & 0.327 & 0.094 & 0.101 & 0.01 & 0.33 & 0.62 & -0.21 \\
\hline GeoB8336-5 & Atlantic Ocean* & $29.21 \mathrm{~S}$ & $12.34 \mathrm{E}$ & 3626 & 0.149 & 0.069 & 0.033 & 0.160 & 0.157 & 0.043 & 0.390 & 0.01 & 0.25 & 0.42 & 0.14 \\
\hline GeoB8342-5 & Atlantic Ocean* & $31.50 \mathrm{~S}$ & $13.00 \mathrm{E}$ & 3521 & 0.143 & 0.053 & b.d. & 0.157 & 0.158 & 0.049 & 0.440 & 0.01 & 0.20 & 0.41 & 0.15 \\
\hline GeoB9526-4 & Atlantic Ocean* & $12.43 \mathrm{~N}$ & $18.06 \mathrm{~W}$ & 3223 & 0.175 & 0.107 & 0.044 & 0.131 & 0.351 & 0.120 & 0.072 & 0.02 & 0.33 & 0.60 & -0.18 \\
\hline GeoB9529-1 & Atlantic Ocean* & $8.35 \mathrm{~N}$ & $17.37 \mathrm{~W}$ & 1234 & 0.326 & 0.080 & 0.047 & 0.198 & 0.220 & 0.064 & 0.065 & 0.02 & 0.45 & 0.36 & 0.24 \\
\hline IS-S2 & Atlantic Ocean & $48.18 \mathrm{~N}$ & $9.71 \mathrm{~W}$ & 1035 & 0.385 & 0.115 & 0.069 & 0.166 & 0.127 & 0.045 & 0.093 & 0.02 & 0.57 & 0.31 & 0.36 \\
\hline ENAM9407 & Atlantic Ocean & $62.96 \mathrm{~N}$ & $4.03 \mathrm{~W}$ & 2060 & 0.408 & 0.082 & 0.027 & 0.146 & 0.233 & 0.065 & 0.039 & 0.02 & 0.52 & 0.36 & 0.24 \\
\hline All-GGC-22 & Atlantic Ocean & $54.79 \mathrm{~S}$ & $3.33 \mathrm{~W}$ & 2768 & 0.377 & b.d. & b.d. & b.d. & b.d. & b.d. & 0.623 & 0.03 & - & - & - \\
\hline T89-32 & Atlantic Ocean* & $14.97 \mathrm{~S}$ & $10.67 \mathrm{E}$ & 3342 & 0.356 & 0.040 & b.d. & 0.190 & 0.130 & b.d. & 0.284 & 0.07 & 0.40 & 0.24 & 0.51 \\
\hline T89-40 & Atlantic Ocean* & $21.62 \mathrm{~S}$ & $6.78 \mathrm{E}$ & 3060 & 0.173 & 0.034 & b.d. & 0.184 & 0.117 & b.d. & 0.491 & 0.01 & 0.21 & 0.30 & 0.37 \\
\hline NP-07-13-09 a & Svalbard & $79.07 \mathrm{~N}$ & $10.67 \mathrm{E}$ & 326 & 0.120 & 0.149 & 0.057 & 0.126 & 0.274 & 0.051 & 0.223 & 0.02 & 0.33 & 0.63 & -0.24 \\
\hline NP-07-13-49 a & Svalbard & $79.01 \mathrm{~N}$ & $11.38 \mathrm{E}$ & 380 & 0.123 & 0.170 & 0.066 & 0.113 & 0.292 & 0.047 & 0.189 & 0.01 & 0.36 & 0.66 & -0.29 \\
\hline HS 253 & Southern Ocean & $75 \mathrm{~S}$ & $26 \mathrm{~W}$ & unknown & 0.099 & 0.051 & 0.018 & 0.129 & 0.168 & 0.044 & 0.492 & 0.02 & 0.17 & 0.49 & 0.02 \\
\hline GeoB10016-2 & Indian Ocean & $1.60 \mathrm{~N}$ & $96.66 \mathrm{E}$ & 1900 & 0.518 & 0.088 & 0.053 & 0.174 & 0.092 & 0.028 & 0.047 & 0.02 & 0.66 & 0.21 & 0.58 \\
\hline GeoB10040-3 & Indian Ocean & $6.48 \mathrm{~S}$ & $102.86 \mathrm{E}$ & 2605 & 0.346 & 0.083 & 0.044 & 0.127 & 0.209 & 0.065 & 0.126 & 0.01 & 0.47 & 0.38 & 0.21 \\
\hline NIOP 902 & Indian Ocean & $10.78 \mathrm{~N}$ & $51.58 \mathrm{E}$ & 459 & 0.241 & 0.118 & 0.077 & 0.273 & 0.091 & 0.031 & 0.170 & 0.03 & 0.44 & 0.29 & 0.39 \\
\hline NIOP 903 & Indian Ocean & $10.78 \mathrm{~N}$ & $51.66 \mathrm{E}$ & 789 & 0.210 & 0.110 & 0.072 & 0.218 & 0.144 & 0.035 & 0.211 & 0.02 & 0.39 & 0.37 & 0.23 \\
\hline NIOP 904 & Indian Ocean & $10.79 \mathrm{~N}$ & $51.77 \mathrm{E}$ & 1194 & 0.198 & 0.116 & 0.068 & 0.187 & 0.139 & 0.043 & 0.249 & 0.02 & 0.38 & 0.40 & 0.18 \\
\hline NIOP 907 & Indian Ocean & $10.80 \mathrm{~N}$ & $52.25 \mathrm{E}$ & 2807 & 0.559 & b.d. & b.d. & 0.441 & b.d. & b.d. & b.d. & 0.01 & - & - & - \\
\hline NIOP 908 & Indian Ocean & $10.78 \mathrm{~N}$ & $52.92 \mathrm{E}$ & 3572 & 0.193 & 0.070 & 0.045 & 0.151 & 0.224 & 0.069 & 0.247 & 0.02 & 0.31 & 0.46 & 0.07 \\
\hline Box 476 & Arabian Sea & $24.10 \mathrm{~N}$ & $65.47 \mathrm{E}$ & 1226 & 0.140 & 0.063 & 0.045 & 0.178 & 0.105 & 0.040 & 0.430 & 0.03 & 0.25 & 0.35 & 0.28 \\
\hline PM1 & Peru Margin & $11.98 \mathrm{~S}$ & $77.32 \mathrm{~W}$ & 100 & 0.261 & 0.047 & 0.026 & 0.314 & 0.042 & 0.005 & 0.305 & 0.02 & 0.33 & 0.13 & 0.81 \\
\hline PM7 & Peru Margin & $11.05 \mathrm{~S}$ & 78.07 W & 250 & 0.247 & 0.037 & 0.024 & 0.219 & 0.050 & 0.008 & 0.415 & 0.03 & 0.31 & 0.16 & 0.73 \\
\hline $\mathrm{F} 1-3^{\mathrm{b}}$ & East China Sea & $30.00 \mathrm{~N}$ & $123.99 \mathrm{~W}$ & 63 & 0.169 & 0.135 & 0.111 & 0.255 & 0.123 & 0.050 & 0.156 & 0.07 & 0.42 & 0.38 & 0.22 \\
\hline$F 4-7^{b}$ & East China Sea & $27.38 \mathrm{~N}$ & $123.33 \mathrm{~W}$ & 106 & 0.144 & 0.179 & 0.128 & 0.139 & 0.175 & 0.062 & 0.172 & 0.07 & 0.45 & 0.56 & -0.10 \\
\hline Cariaco Basin & Caricaco Basin & $10.67 \mathrm{~N}$ & $65.60 \mathrm{~W}$ & 1460 & 0.339 & 0.041 & 0.023 & 0.381 & 0.031 & 0.008 & 0.176 & 0.01 & 0.40 & 0.09 & 1.00 \\
\hline MC-1 & Pacific Ocean & $41.30 \mathrm{~N}$ & $141.55 \mathrm{E}$ & 1002 & 0.177 & 0.143 & 0.062 & 0.182 & 0.194 & 0.049 & 0.194 & 0.02 & 0.38 & 0.48 & 0.03 \\
\hline
\end{tabular}


BS 07E

Black Sea

$43.0 \mathrm{~N} \quad 34.0 \mathrm{E}$

1288

0.216

0.117

0.071

0.186

$0.177 \quad 0.028$

0.204

0.40

$0.42 \quad 0.13$

${ }^{\mathrm{a}}$ data from Peterse et al. (2009); ${ }^{\mathrm{b}}$ data from Zhu et al. (2011) 
Table 4: Fractional abundances and indices of brGDGTs and crenarchaeol present in surface sediments of the Congo deep sea river fan (from Weijers et al., 2007a). The two anker samples represent grab samples taken from the Congo River estuary (cf. Schefuß et al., 2004). Roman numerals refer to the GDGT structures in Fig. 1; 'b.d.' = below detection limit; '-' indicates that the respective indices are not calculated due to absence of GDGTs.

\begin{tabular}{|c|c|c|c|c|c|c|c|c|c|c|c|c|c|c|c|}
\hline \multirow{2}{*}{$\begin{array}{c}\text { Sample } \\
\text { ID }\end{array}$} & \multirow[b]{2}{*}{ Latitude } & \multirow[b]{2}{*}{ Longitude } & \multirow{2}{*}{$\begin{array}{c}\text { Water } \\
\text { depth } \\
(\mathrm{m})\end{array}$} & \multicolumn{8}{|c|}{ GDGT fractional abundance } & \multirow[b]{2}{*}{ BIT } & \multirow[b]{2}{*}{ MBT' } & \multirow[b]{2}{*}{ DC } & \multirow[b]{2}{*}{ CBT } \\
\hline & & & & $f($ la) & $f(\mathrm{lb})$ & $f(I c)$ & $f(\mathrm{Ila})$ & $f(\mathrm{Ilb})$ & $f(I I c)$ & $f($ IIla) & $f(\mathrm{IV})$ & & & & \\
\hline Anker 24 & $6.03 \mathrm{~S}$ & $12.57 \mathrm{E}$ & 5 & 0.712 & 0.054 & 0.016 & 0.140 & 0.019 & 0.003 & 0.015 & 0.041 & 0.95 & 0.82 & 0.08 & 1.06 \\
\hline Anker 26 & $6.05 \mathrm{~S}$ & $12.48 \mathrm{E}$ & 6 & 0.584 & 0.062 & 0.038 & 0.192 & 0.026 & 0.008 & 0.033 & 0.056 & 0.94 & 0.72 & 0.11 & 0.94 \\
\hline T89-12 & $5.20 \mathrm{~S}$ & $7.97 \mathrm{E}$ & 4068 & 0.193 & 0.034 & 0.009 & 0.080 & 0.028 & 0.003 & 0.050 & 0.604 & 0.35 & 0.59 & 0.20 & 0.64 \\
\hline T89-14 & $3.51 \mathrm{~S}$ & $9.69 \mathrm{E}$ & 868 & 0.029 & 0.004 & 0.002 & 0.007 & 0.007 & 0.002 & 0.009 & 0.939 & 0.05 & 0.58 & 0.29 & 0.50 \\
\hline T89-15 & $4.21 \mathrm{~S}$ & $10.02 \mathrm{E}$ & 1930 & 0.128 & 0.010 & b.d. & 0.019 & 0.018 & b.d. & 0.015 & 0.809 & 0.17 & 0.73 & 0.18 & 0.72 \\
\hline T89-16 & $5.71 \mathrm{~S}$ & $11.23 \mathrm{E}$ & 826 & 0.280 & 0.014 & 0.005 & 0.037 & 0.009 & b.d. & 0.016 & 0.638 & 0.34 & 0.83 & 0.07 & 1.15 \\
\hline T89-19 & $6.04 \mathrm{~S}$ & $9.96 \mathrm{E}$ & 3140 & 0.413 & b.d. & b.d. & 0.047 & b.d. & b.d. & b.d. & 0.540 & 0.46 & - & - & - \\
\hline T89-20 & $7.31 \mathrm{~S}$ & $11.54 \mathrm{E}$ & 1080 & 0.102 & 0.005 & 0.002 & 0.013 & 0.007 & 0.002 & 0.008 & 0.861 & 0.12 & 0.79 & 0.10 & 0.96 \\
\hline
\end{tabular}


Table 5: Average BIT, MBT' and DC indices and CBT ratios of the different sample groups discussed in the text. Numbers in parentheses are standard deviations; 'n.a.' = not applicable since samples were selected based on their BIT index values.

\begin{tabular}{|c|c|c|c|c|}
\hline Sample group & BIT & MBT' & DC & CBT \\
\hline Global soilsa & $0.90(0.15)$ & $0.49(0.23)$ & $0.16(0.15)$ & $0.96(0.59)$ \\
\hline African soils ${ }^{a}$ & $0.85(0.20)$ & $0.76(0.22)$ & $0.13(0.18)$ & $1.28(0.79)$ \\
\hline Dust filters & $0.25(0.08)$ & $0.80(0.06)$ & $0.11(0.04)$ & $0.95(0.17)$ \\
\hline Surface water & $0.23(0.25)$ & $0.89(0.01)$ & $0.06(0.04)$ & 1.24 (0.33) \\
\hline Congo fan & $0.42(0.35)$ & $0.72(0.10)$ & 0.15 (0.08) & $0.85(0.24)$ \\
\hline African Atlantic & n.a. & $0.28(0.10)$ & $0.39(0.16)$ & $0.21 \quad(0.31)$ \\
\hline Global marine & n.a. & $0.35(0.12)$ & $0.40(0.16)$ & $0.20(0.32)$ \\
\hline
\end{tabular}

Table 6: Results of the ANOVA pairwise multiple comparison test. Values in bold indicate that the mean difference between the respective sample groups is significant at the $90 \%$ confidence level. Group numbers correspond to the following sample groups (cf. Fig. 4): $1=$ global soils, 2 $=$ African soils, $3=$ dust, $4=$ surface water SPM, $5=$ Congo deep sea fan sediments, $6=$ low latitude Atlantic Ocean sediments with BIT values $<0.08,7=$ global marine sediments with BIT $<0.08$.

\begin{tabular}{ccccccc}
\hline Group & 1 & 2 & 3 & 4 & 5 & 6 \\
\hline 2 & 1.000 & - & - & - & - & - \\
3 & 0.465 & 1.000 & - & - & - & - \\
4 & 0.525 & 0.957 & 0.996 & - & - & - \\
5 & 1.000 & 1.000 & 0.997 & 0.740 & - & - \\
6 & $\mathbf{0 . 0 8 6}$ & $\mathbf{0 . 0 6 2}$ & $\mathbf{0 . 0 2 4}$ & $\mathbf{0 . 0 1 1}$ & $\mathbf{0 . 0 6 5}$ & - \\
7 & $\mathbf{0 . 0 0 0}$ & $\mathbf{0 . 0 0 0}$ & $\mathbf{0 . 0 0 0}$ & $\mathbf{0 . 0 0 0}$ & $\mathbf{0 . 0 0 0}$ & 1.000 \\
\hline
\end{tabular}




\section{Figure captions}

Figure 1: Structures of glycerol dialkyl glycerol tetraethers (GDGTs) referred to in the text

Figure 2: Sample location map: A) sample locations of marine surface sediments; B) sample locations of dust, surface waters and Congo deep sea fan sediments along the equatorial African coast.

Figure 3: Cross plot of the degree of cyclisation (DC) and the methylation index (MBT') of brGDGTs of the different sample groups discussed in the text.

Figure 4: Box plots of DC indices for the different sample groups discussed in the text. Horizontal solid line within the boxes represents the median, gray boxes comprise $50 \%$ of samples and dots beyond the whiskers represent upper- and lowermost $10 \%$ of samples. No whiskers plotted if $n<10$. The soil data used are those from Peterse et al. (2012). African soils and low latitude Atlantic sediments are subsets of global soils and global marine sediments, respectively. Groups that are statistically significantly different from each other (at $90 \%$ confidence level) are assigned different letters.

Figure 5: Degree of cyclisation (DC index) of brGDGTs in coastal and shelf sediments from the East China Sea (ECS) shelf plotted against water depth, which in the ECS is in general equivalent to distance from the coast. Red triangles indicate sediments shallower than $10 \mathrm{~m}$; 
these shallow sediments are generally characterised by high BIT indices (average $=0.86$ ).

Data from Zhu et al. (2011). 


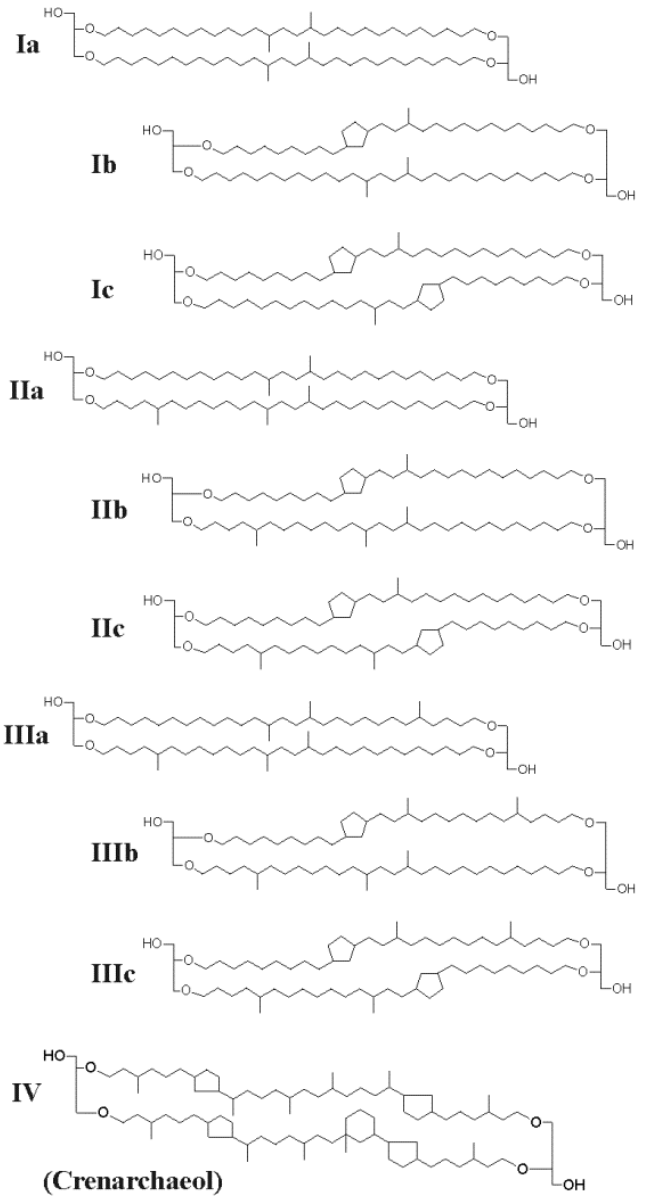

Figure 1 

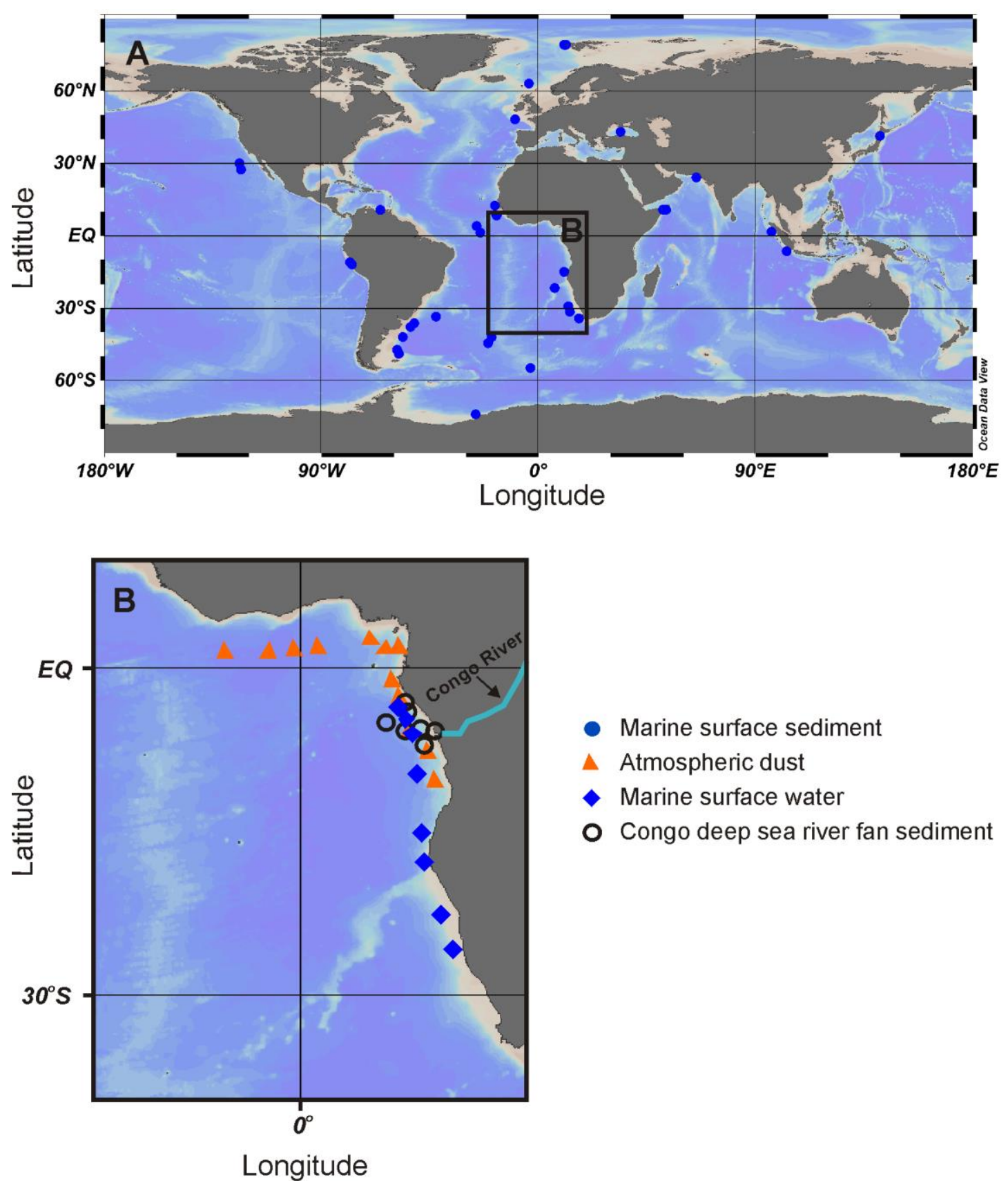

- Marine surface sediment

- Atmospheric dust

- Marine surface water

- Congo deep sea river fan sediment

Figure 2 


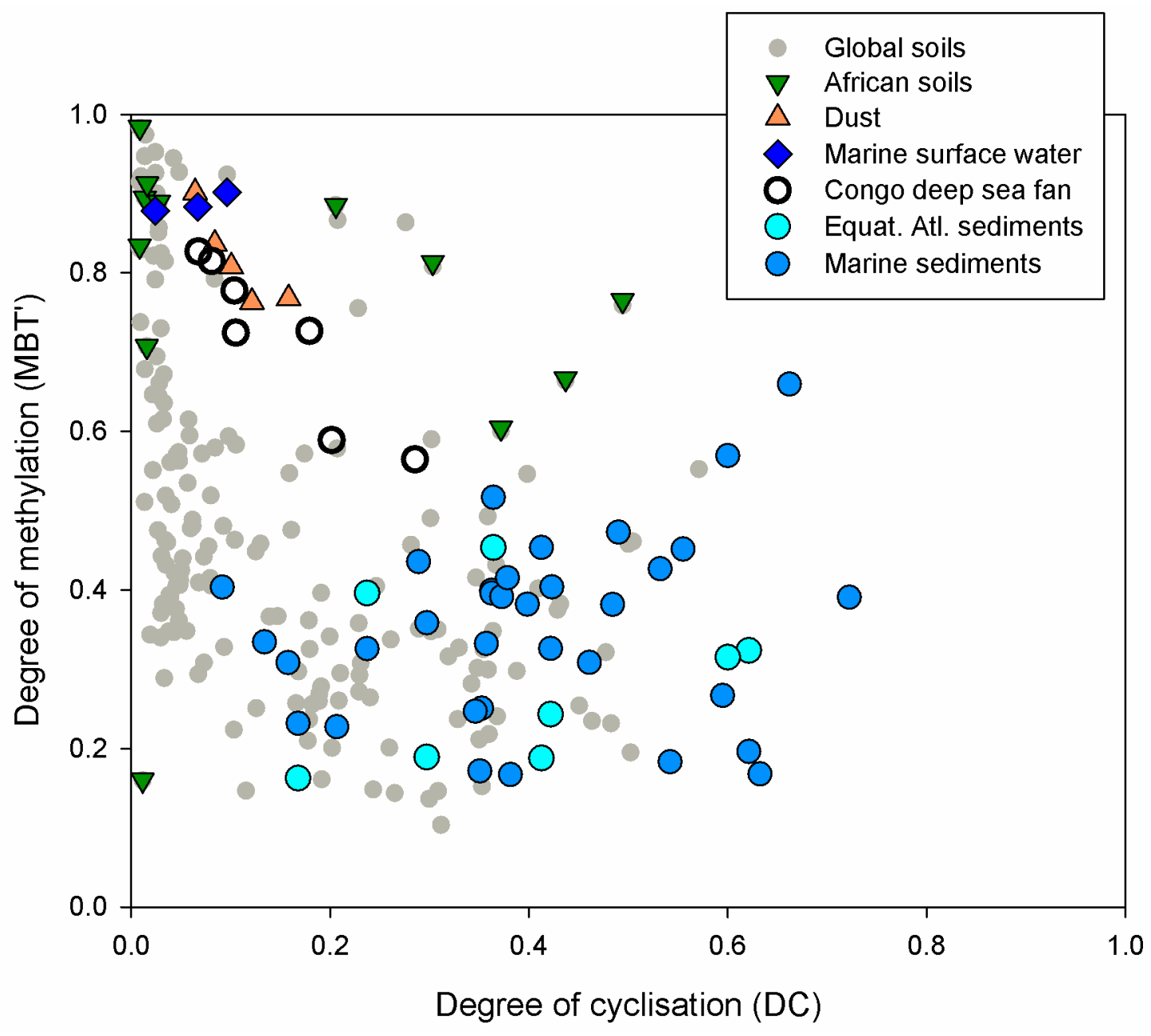

Figure 3 


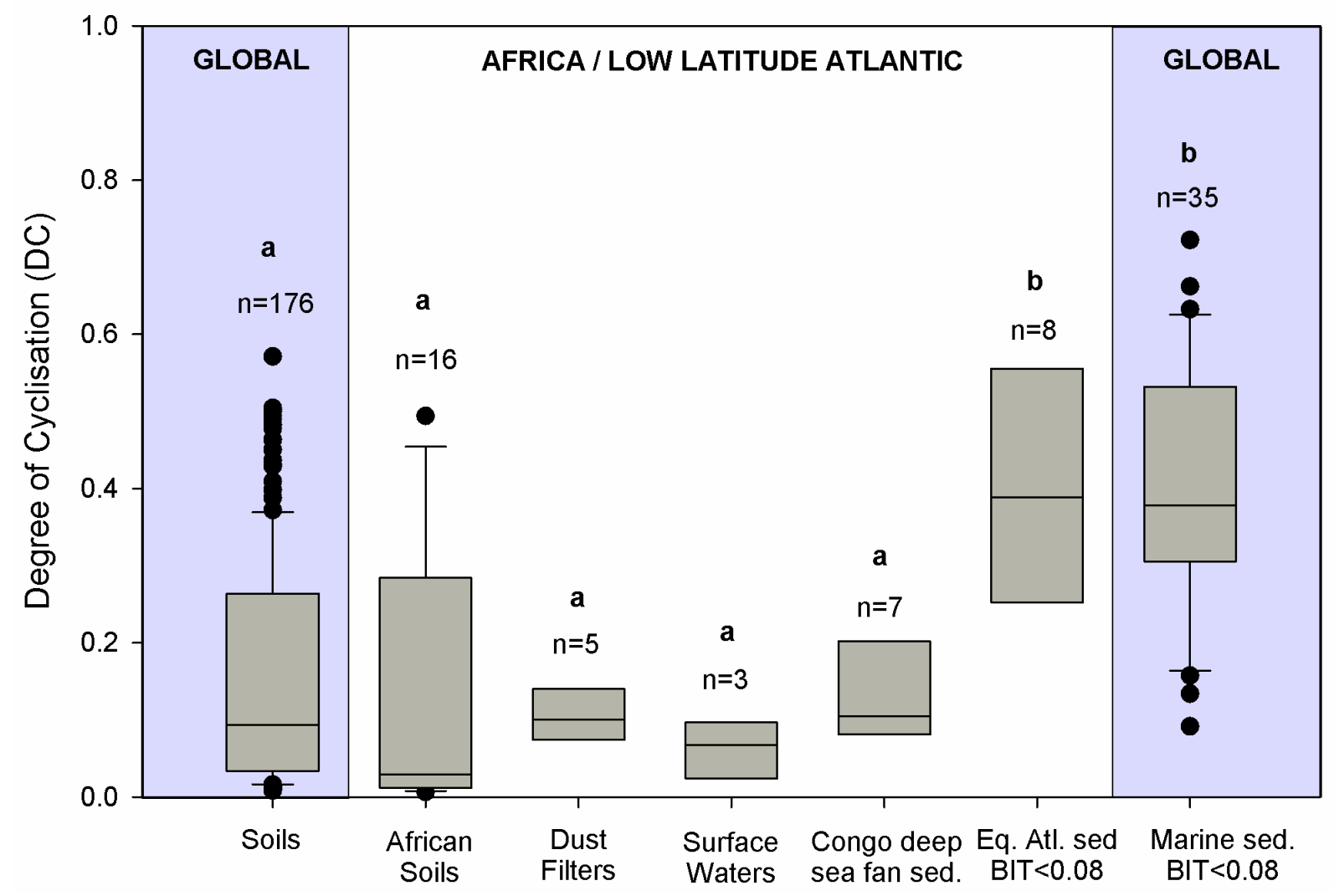

Figure 4 


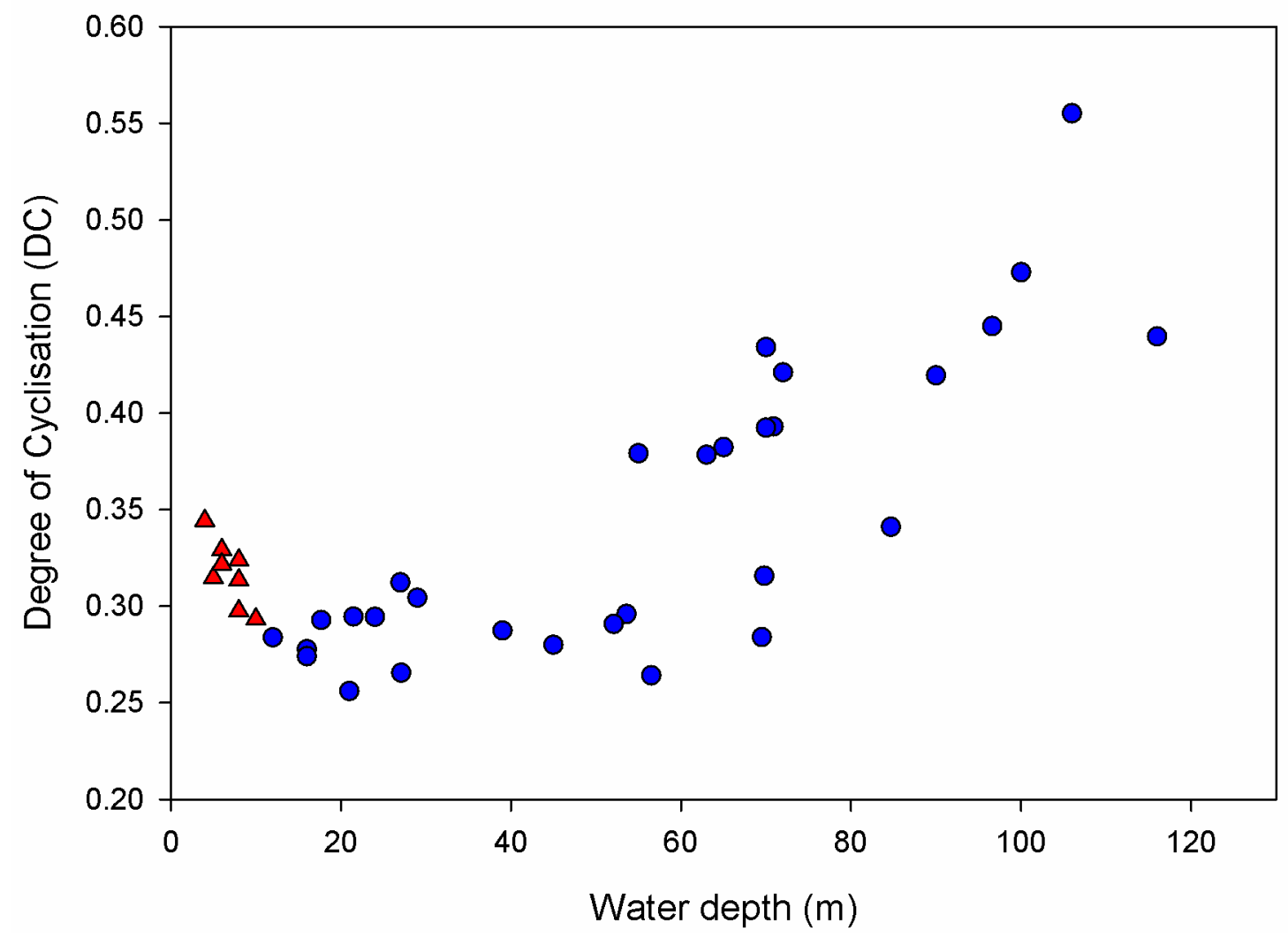

Figure 5 